\title{
A Case Study of Computer Assisted American Literature Teaching
}

\author{
Huang Xiuguo ${ }^{1}$, Chang Xiaomei ${ }^{2}$, Xing Luwei ${ }^{3}$ \\ ${ }^{1,2,3}$ School of Interpretation \& Translation, Shandong University at Weihai. \\ Weihai, Shandong Province, PRC, 264209 \\ Email:xiuguohuang@126.com
}

\begin{abstract}
Keywords: English Major; Computer Assisted; American Literature Course
Abstract: American literature course also called American Literature History and Anthology is among the important courses of English majors that meant to improve Chinese students' cross-cultural ability and better their language proficiency. However, the outdated teaching methodology frustrated students' interest and motivation. Traditional paper edition was just one choice and has lost its edge in competition with the fast-developed and ever-changing multimedia. Students are often bored with the traditional teaching methods. Nevertheless, they can be motivated by the more lively and colorful multimedia teaching. As to the proper procedure of the employment of multimedia and potential hazard of improper use of it, there is no definite answer. This paper based on the investigation conducted in Shandong University at Weihai attempted to analyze the problems in the course of teaching and to propose some suggestion for further improvement of American Literature teaching.
\end{abstract}

\section{Introduction}

American literature course is a compulsory course for English Majors in Chinese universities. Its purpose is to cultivate Chines students' ability to read, appreciate, and understand British and American literary works, to be familiar with the literature criticism. Through the reading and analysis of English and American literature works, to improve students' language and cultural capability, to enhance the students' understanding of the western literature and the Western culture. English and American literature should have fulfilled the promise to enhance students' intercultural communicative competence. Literature is the cream of culture, whose content is rich and colorful. The selected writers and works are time-tested masterpieces, which should have made American literature course a subject of interest that can contribute to the overall development of students' ability. However, the result is most undesirable. And it is mainly because of the teachers' outdated pedagogical methodology.

According to Cheng Aimin's investigation, now in China's colleges and universities, "more than $60 \%$ of the teachers are still using the traditional teaching mode that is the blackboard, chalk, textbook model”. [1]What is most common in the British and American literature class in China is that the teacher keep writing well-established criticism and comments on the blackboard, while students keep taking notes. And after class, the students kept reciting notes to prepare for examination. To a certain degree, British and American literature class has become a dictation exercise. The text books are the core of teaching, and the teachers meant to disseminate literary knowledge to the students. The students are passive receiver of knowledge and hardly had any participation. So in the eyes of the students, American literature course is boring. The employment of multimedia can make the class more lively, interesting and colorful. But among teaching experts there are still disagreements about the use of multimedia in literature classes. They argue against "the use of hypertextual resources without careful pedagogical understanding of the dangers they present of encouraging students to become passive consumers rather than active thinkers"[2].

Taking this into consideration, we tend to reform the teaching in American literature class by introducing modern education technology into classroom. The popularization of the multimedia technology has provided the technical support for the reform. Multimedia teaching made it possible to use audios, videos, and PPT in classes. The students can also have discussion on the internet. Compared with traditional teaching, multimedia teaching is certainly more "colorful, diverse, novel, 
intuitive, rich and interesting"[3]. And it can stimulate student's interest in learning and to turn them into active performers in class. But how to use the multimedia in the literature class it is still a question. In order to evaluate the employment of multimedia in literature class, we had an experiment lasting for two semesters in the America literature class. Our experiment subject is the undergraduates of English majors of grade 2009 in Shandong University at Weihai.

\section{Purpose and Method of Experiment}

Experiment Design: Two natural classes in this paper are referred to as class A and class B. To make sure the contrast accurate, there is a strict control of the factors that might influence the results of the experiment, such as the class size, English level, and the teachers and so on. Class A uses multimedia teaching mode; class B uses the traditional teaching method. The experiment lased for two semesters. Experiment purpose: Compare the teaching effect between the class that used of multimedia and the class with traditional teaching methodology. Experimental hypothesis: teaching effect of the class aided by multimedia is better than the teaching effect of traditional methods. Data analysis tool: SPSS software

\section{Results and Analysis of the Experiment:}

Because the students have learned British literature for one year, so in the beginning the students' test scores in British literature were first analyzed.

Table 1. Statistical Analysis of students' British literature test scores before the experiment

\begin{tabular}{|cc|c|r|r|l|}
\hline \multicolumn{2}{|c|}{ Class } & $\mathrm{N}$ & Mean & Std Deviation & sig \\
\hline score & $\mathrm{A}$ & 30 & 75.2333 & 7.65949 & 0.54 \\
& $\mathrm{~B}$ & 30 & 76.4333 & 7.53238 & \\
\hline
\end{tabular}

According to table 1, we can see the average score of class A and class B is pretty close, and there is no sharp difference in the standard deviation. The Sig value is 0.54>0.05, and the differences in the literature performance of the two classes are not obvious.

After two semesters' experiment, we have an analysis of the students' test scores of American literature.

Table 2. Statistical analysis of the results of the students' American Literature test scores after two semesters

\begin{tabular}{|c|c|c|c|c|c|}
\hline & Class & $\mathrm{N}$ & Mean & Std Deviation & sig \\
\hline \multirow[t]{2}{*}{ score } & A & 30 & 80.0000 & 5.19283 & 0.03 \\
\hline & B & 30 & 76.7667 & 6.03257 & \\
\hline
\end{tabular}

Table 2 shows that the average score of the two classes has showed a significant difference between these two classes. The Sig value is 0.03 to 0.05 . This can prove that the use of different teaching methods has a significant influence on the learning effect. The class with computer assisted teaching has a better performance than the one with the use of traditional teaching methods.

For Chinese undergraduates, the American literature contains a lot of historical information and facts. Therefore the test paper usually consists of four parts: part one explanation of literary terms, part two filling in the blanks, part three identification of the sources of a certain excerpt and part four comprehensive questions. Through a comparison of the examination performance between these two classes, it is clearly revealed that students from both classes got pretty close scores on the literature knowledge part that is part one and part two. The difference in their score is mainly resulted from the different performances on part three and part four. Students from class A showed deeper and also more comprehensive understanding of the literary works. Their answers probe 
through the superficial and general comment into the sphere of innovative and original understanding. And also more information relevant to their personal experience is used in their answers.

Further investigation showed that there is no significant difference in their study attitude. Students from class B also worked very hard in their literature class. There are no significant personal factors in their different performance in examination. Also as the British literature test has showed previously class A and class B had no significant difference in students' language capability. Therefore, we can say that the difference is mainly caused by the different teaching methodologies. And students from class A also pointed out that multi-media teaching made the literary texts more impressive and triggered their interest in the original works. This all made it easier to for them to prepare for the examination and get satisfactory score. "The computer-assisted classroom enables the instructor to plan for and assess learning in multiple modes and multiple contexts" [4]. This teaching methodology proved rather effective.

In computer assisted classes, students also have the opportunity to have on-line discussions. We have the members of the group responsible for what they discussed. This makes it possible for them to have authority over what they expressed. In the on-line discussion, the participation asks students to read as many books as the topic required. During this process, they usually have to read more than the books on the teacher-made booklists. After reading these references, they have to think and communicate with others. They have to read more than they write. Besides, they have to evaluate and comment on others' reflection and thoughts. And the responding process is not a test of speed, and therefore they don't have to rush to say something. When they do respond to others' comment, it is the result of careful thinking. They can evaluate each other's new thoughts and points of view that are different from their own. Through focusing on critical and reflective reading, they paid more attention to the ideas that this process produces. This also enables them to produce more insightful writing during the examination.

\section{Feedbacks from the students}

Considering the obvious positive effect of computer assisted class proved by the experiment, all the American literature classes in the School of Interpretation and Translation in Shandong University at Weihai adopted the Multimedia assisted teaching. In order to investigate their personal feelings on the employment of multimedia, We randomly choose 20 students from four classes (the size of the class of English majors is quite small and there are about 30 students in each class), a total of 80 students to accomplish another survey. They all use the same text book "American Literature History and Anthology "(Foreign Language Teaching and Research Press, 2013) edited by Wu Weiren.

The type of the questionnaire is all multiple choices, with only one correct answer, but two open questions. Altogether, 80 questionnaires were distributed and all were recalled. There are 78 effective questionnaires, and the effective rate was $97.5 \%$. After the investigation, we make a quantitative analysis of the data. In addition, we also paid close attention to students' attitude and reaction during the teaching process. In this way, our analysis and proposals are very reliable.

Table 1. Personal experience of the multimedia-aided teaching effect and traditional teaching effect

\begin{tabular}{|l|l|l|l|}
\hline & $\begin{array}{l}\text { multimedia-aided } \\
\text { teaching effect } \\
\text { better }\end{array}$ & same effect & $\begin{array}{l}\text { traditional teaching } \\
\text { effect better }\end{array}$ \\
\hline number of students & 62 & 4 & 12 \\
\hline percentage & $79.5 \%$ & $5 \%$ & $15.5 \%$ \\
\hline
\end{tabular}

The majority of all the students, about $80 \%$, agreed that multimedia-aided teaching is more interesting and has better effect. A further investigation of the reasons behind the students' choice revealed that the students felt that the multimedia-aided teaching was more flexible, vivid, 
interesting, and more informative. They can also enjoy some of the film clips in class to deepen their understanding of literary works. These are some of the most obvious advantages multimedia-aided teaching. Through the results, we can see the majority of students preferred the multimedia teaching mode, but still $15.5 \%$ of the students think that the traditional teaching method better. Through further investigation, we find the reason is that they believe the amount of information in multimedia-aided teaching is too much. They are in the habit of taking down notes as they do in traditional classes, but it is very hard for them to keep the pace with so much information carried by multimedia.

Table 2. The reception of information in multimedia-aided teaching

\begin{tabular}{|l|l|l|l|}
\hline & $\begin{array}{l}\text { multimedia-aided } \\
\text { teaching better }\end{array}$ & no difference & $\begin{array}{l}\text { multimedia-aided } \\
\text { teaching worse }\end{array}$ \\
\hline number of students & 60 & 10 & 8 \\
\hline percentage & $76.9 \%$ & $12.8 \%$ & $10.3 \%$ \\
\hline
\end{tabular}

The majority of students believe that the amount of knowledge in the multimedia teaching is bigger and the effect is better. The multimedia teaching can supplement background knowledge and information and improve the teaching effect. But $10.3 \%$ of the students think that the traditional teaching better, because in traditional classes they can make precise notes of all the important information and it's easier to memorize.

Table 3. the effect of the use of videos

\begin{tabular}{|l|l|l|l|}
\hline & good & ok & bad \\
\hline number of students & 68 & 4 & 6 \\
\hline percentage & $87 \%$ & $8 \%$ & $5 \%$ \\
\hline
\end{tabular}

The majority of students welcomed the use of audio-visual contents. They believed that it could help them deepen the understanding of the literature works. We specifically chose the masterpiece of Mark Twain, The Adventures of Huckleberry Finn, as an example and made a comparison between different classes. One class is deliberately chosen to have American literature courses in a completely traditional way. The students of other classes are able to watch a clip of the film adaptation. Through later examination, we find the difference is obvious. The students who are able to able to watch video clip have deeper impression and understanding of The Adventures of Huckleberry Finn aided by film.

Table 4. The overall impression of multimedia-aided teaching

\begin{tabular}{|l|l|l|l|}
\hline & excellent & better & bad \\
\hline number of students & 28 & 46 & 4 \\
\hline percentage & $35.8 \%$ & $58.9 \%$ & $5.3 \%$ \\
\hline
\end{tabular}

94\% of the students think that the learning effect of multimedia-aided teaching is good. The majority of the students think that through the aid of multimedia, they became more interested in American literature and bettered their English proficiency. This coincides with the findings of Brett (1996). When investigating learners' attitudes towards multimedia, Brett found that $86.9 \%$ of students believed that a multimedia application they were introduced to would improve their listening skills.

\section{Suggestion and Proposals for Computer Assisted American Literature Teaching}

Jack Mezirow's (1991) transformative learning theory proposes that learning can significantly change learners' cognitive, sociolinguistic and psychological point views. And in this way it can transform the learners themselves. This is emphasizing the effect of learning on the learners. On the 
other hand, the learners' unique experience can also influence the teaching mode. Facing a new generation that had got used to all kinds of multimedia in their lives, our teaching methodology also should be transformed to suit their needs. It has been confirmed that the outdated teaching methodology frustrated students' interest and motivation. Completely traditional teaching has lost its edge in competition with the fast-developed and ever-changing multimedia-aided teaching. Students are often bored with the traditional teaching methods. They can be motivated by the more lively and colorful multimedia teaching. Nevertheless, there are certain dos and don'ts we should pay attention to.

First of all, as some students have already pointed out, there was the problem of the proper amount of information. Usually there is more information provided by the multimedia-aided teaching. In certain cases they could become a burden. We suggest that we should streamline the information in the course of the literature class. Only the most important and enlightening information are stressed in the classroom. Other supplementary materials should be dealt after class.

Second, as for the use of audio-visual materials, teachers should be very familiar with the content of the film. That means teachers should make more preparation before the class and their amount of work is increased. And not all the literary works have suitable films and video resources that we can turn to. What's more, there should be a proper extent of the use of audio and video resources. The more the better doesn't work here. After all, literature class is not a film appreciation course. Our original intention is to draw students' attention back to English literary works not to drive them to film adaptation.

Third, a very common problem for today's college students in China is that they read less and less. Without sufficient reading, there is no appreciation of literature. This is also a tricky issue in front of all the literature teachers. The Students are more interested in cartoons, pictures, TVs and films, but they didn't want to read books. Especially, they tried all means to shy away from reading the chunky masterpieces. There is no simple solution to this conundrum. On the one hand, for these Chinese students, English is a very difficult second language, which means to understand the original literary works needs a lot of thinking and is a strenuous job. On the other hand, in China the amount of foreign language books resources is still small. And sometimes it is hard for them to find a certain book. The use of computer-aided teaching can to some extent solve this question. School of Interpretation and Translation in Shandong University at Weihai from grade 2005 opened a new course called Internet reading for the students. With the use of electronic books and electronic software, more and more students are accessible to original works in the multimedia classroom. At the same time, we also introduced more websites to students, which they can visit anytime and anywhere suitable for them.

Last, there is also the issue of the curriculum of American literature. Through the investigation, we found a lot of students complained that the literature course that is designed to be conducted in the second semester of the junior year and the first semester of senior year is kind of lagging behind, which also affected the effect of learning. Right now in China, in the senior year, the students are generally faced with issues like the problem of choosing a specific career, sitting for all kinds of examinations for certificates and also the postgraduate entrance examination. This means that at this time, they can spare less time to read these chunky books. If the American literature course is opened one semester earlier, the effect should be more desirable.

\section{Conclusion}

In recent years, in China there has been a lot of discussion on the reform of English teaching. But most of these researches have been on the Public English course for students of other majors than English, the English majors are often overlooked. We deeply believe that more attention should be to the teaching of compulsory courses for English majors, because the effect of the teaching for English majors will ultimately determine the overall teaching effect of English in China. The graduates of English majors are the future English teachers. Their interest, their language proficiency, and their cross-cultural capability will eventually determine the English teaching in 
China. American literature as a compulsory course for English majors, its importance can't be overlooked. We hope the reform of American literature teaching will benefit the English majors and also all the English learners.

\section{Acknowledgements}

This work was financially supported by the Teaching Research Project of Shandong University at Weihai (B201413).

\section{References:}

[1] Cheng Aimin: Foreign Language Research Vol.1 (2002), p.14

[2] Rosanne G Potter: Computers and the Humanities Vol.2 (1996), p.181

[3] Lin Xunzi: The Computer-assisted Language Teaching Vol.10 (2006), p.69

[4] Marguerite Jamieson, Rebecca Kajs and Anne Agee: Computers and the Humanities. Vol.2 (1996), p. 164

[5] J. Mezirow: Transformative Dimensions of Adult Learning (Jossey-Bass, USA 1991). 